\title{
On psychological aspects of translation
}

\author{
Bruno Osimo \\ Istituto Superiore Interpreti Traduttori \\ via Alex Visconti 18, 20151 Milano, Italy \\ e-mail: osimo@libero.it
}

\begin{abstract}
Translation science is going through a preliminary stage of selfdefinition. Jakobson's essay "On linguistic aspects of translation", whose title is re-echoed in the title of this article, despite the linguistic approach suggested, opened, in 1959, the study of translation to disciplines other than linguistics, semiotics to start with. Many developments in the semiotics of translation - particularly Torop's theory of total translation - take their cue from the celebrated category "intersemiotic translation or transmutation" outlined in that 1959 article. I intend to outline here the contributions that the science of translation - following a semiotic perspective opened by Peirce and continued by Torop - can gather from another discipline: psychology. The "totalistic" approach to translation provided by Torop can be more deeply enforced by applying to it the consequences deriving from the psychological insight offered by the concept of "interpretant" as mental sign; the perceptual interpretation of the prototext; reading and writing as intersemiotic translation processes; unlimited semiosis as interminable analysis; primary and secondary process in dreams and in other kinds of translation; metaphor and disambiguation as mental processes; the defenses activated when translation criticism (review) and self-criticism (revision) are made.
\end{abstract}

There are days when everything I see seems to me charged with meaning: messages it would be difficult for me to communicate to others, define, translate into words [...]. (Calvino 1998: 55).

\section{From psycholinguistics to psycho-semio-translation}

Psycholinguistic approaches to translation traditionally focus on a behavioral analysis of translation. Translation is considered as a behavior, and the focus of analysis is "the problem of investigating translator- 
behavior" (Bell 1998: 189). A translator is compared to a hardware component: "All text processing is, to a large extent, a matter of problem solving. Translators, just like other text-processors, encounter problems [...]" (Bell 1998: 187). One of the main issues is memory. As in the behavioural tradition, the translator is considered a "black box", out of focus, while the analysis is on the input and the output, cause and effect. Such an approach tends to consider translational behaviour on a large, objective, scale, rather than the subjective mechanisms underlying text interpretation. Moreover, "translation" means here just "interlingual translation".

After all a translator, and even more so a translation researcher, is induced to think in terms of passing directly from prototext to metatext by the evaluative-oriented exercises occurring in his higher schooling; by the existence and use of bilingual dictionaries, that are presented not as temporary, tentative, incomplete and potentially misleading aids, but as lists of "equivalents"; by the existence of monolingual dictionaries, that are presented not as lists of partial and possible interpretations, but as lists of "meanings"; and by the low awareness of translation processes (also in terms of perception, reading, writing) in our culture.

I don't consider translation as a mental activity on its own, but as a set of specific operations ranging from reading to writing, from interpreting to reviewing, on which a vast psychological literature is available. I see each process - reading, for example — in terms of intersemiotic translation from one type of code to another - from verbal code to mental code, in this example.

Translators do not limit themselves to input-output, source-target transfer, like telegraph operators transcribing the dots and lines of Morse code into the Latin (or other natural code) alphabet characters. Language, being used more or less efficiently to communicate with other individuals, does not contradict the subjectivity of the individual's linguistic experience: it undergoes another passage, i.e. the translation from inner speech into the outer world when we want to be understood by another person.

If Freud guessed the existence of an entity - the unconscious that revolutionized the concept of human and free will, contemporary psychology, postulating the existence of an inner language of which we are unaware but we continually use, revolutionizes the way to think of sign-object relations and, in translation studies, prototext sign - metatext sign relations. The active (but often unconscious) participation of the translator's mind in interpreting and reworking the 
text, and the consequent unavoidable infiltration of the translator's personal, private material (affects, sensations, feelings, memories, experiences, traumas, idiosyncrasies, just to name a few) make the translation process an unaware, unwilling manipulation (apart from any willing, outer, ideologically-driven manipulation of which the translator is aware). Reconsidering the not so fortunate spatial-ballistic metaphor of the translation as a path, the translator's mind is another of the places - beyond "source" and "target" — in which translation occurs, all the more interesting and potentially insidious because it is neglected by most arguments on translation. A place of perdition, a Dantean selva, meaning that here occurs the fatidic loss of a part of the message's content that, according to Torop's total translation view, can be recovered only by means of a metatextual translation.

The focus shifts from objectivity to subjectivity, from behavioural psychology to depth psychology — from effects to affects - and from linguistics to semiotics. I use the Peircean approach to the notion of text (everything is a text that is read as a text), the depth-psychology approach to the concept of psyche (subjective affects playing a major role in it), Jakobson's notion of "intersemiotic translation" (everything is a translation that has a prototext and a metatext), and Torop's notion of "total translation" (translation as a key concept in semiotics; everything must be translated) to stir new reflections in the semiotics of translation.

\section{Peirce and translation}

The term "translation" was often used by Peirce referring not to interlingual translation, but to the extraction of meaning from texts. To Peirce the "interpretant" (or "interpretant sign") is that mental sign, that thought, that representation, serving as a mediating tool between sign and object.

Everything may be comprehended or more strictly translated by something: that is has something which is capable of such a determination as to stand for something through this thing; somewhat as the pollen-grain of a flower stands to the ovule which it penetrates for the plant from which it came since it transmits the peculiarities of the latter. In somewhat the same sense, though not to the same degree, everything is a medium between something and something. (Peirce 1982, 1: 333) 
The mental representation of something (in Peirce's simile, the representation of the pollen-grain to the plant) is a sort of mental translation. In other words, the interpretant is also a "translatant" and, in some scholars' opinion, it could be legitimately called by either term without difference. The perception of something (object or sign) translates the perceived thing into a mental representation, or interpretant. Every following perception-translation-interpretation is a recognition, i.e. new interpretation and clarification of the mental representation. "We are capable of understanding representations only by having conceptions or mental representations, which represent the given representation as a representation" (Peirce 1982, 1: 323). A mental representation (interpretant) is such only on condition that it also implies the awareness of being a representation. There is a level of representation (signs) and a level of meta-representation (metasigns). Meaning is built through a less and less uncertain process of truth seeking (Gorlée 1994: 119), progressing from perception to conception to meta-conception: "Consider what effects, which might conceivably have practical bearings, we conceive the object of our conception to have. Then, our conception of these effects is the whole of our conception of the object" (Peirce 1982, 3: 266).

Every read word evokes a quick series of subjective associations, so quick that it often goes unrealized. This process translates the read signs into translatants. Human thought progresses and evolves through a series of translations. As far as such evolution occurs within an individual, translations have interpretant signs both as a prototext and as a metatext, and are then intralingual translations (in this case meaning by "language" the mental subjective language). When the evolution of thought passes from one person to another, interpretants need to be translated into understandable texts (verbal language, body language, etc.); then single receivers must retranslate them into interpretant signs. A double intersemiotic translation occurs. "But a sign is not a sign unless it translates itself into another sign in which it is more fully developed. Thought requires achievement for its own development, and without this development it is nothing. Thought must live and grow in incessant new and higher translations, or it proves itself not to be genuine thought" (Peirce 1931-1966, 5: 594).

Each of these thought translations is a step higher than the previous one; it is not supposed to be a "faithful" translation, but an enrichment of the previous sign. A sign is a body, whose interpretation is the soul. Every sign must have an interpretant, otherwise it is not a sign. "A sign must have an interpretation or signification or, as I call it, an 
interpretant. This interpretant, this significations simply a metempsychosis into another body; a translation into another language. This new version of the thought received in turn an interpretation, and its interpretant gets itself interpreted, and so on, until an interpretant appears which is no longer of the nature of a sign" (Peirce, quoted in Gorlée 1994: 126).

Translation - the very process characterizing reading and, in the following phases, the evolution of the material read - is a fundamental link of semiosis, or sign translation. Some maintain that semiosis is unlimited. Peirce maintains, on the other hand, that the ultimate aim of translation is to reveal the ultimate signification of the sign (Gorlée 1994: 127). Since, however, he doesn't tell if or how it is possible to arrive at this "ultimate" result, Peirce leads us to believe that there is always room for further translation-interpretation-reading: semiosis, reading, translation never end, it is always possible to enrich interpretation with new elements.

\section{Inner speech}

The language in which we think, the language in which we dream, is not a natural code. Of course, it is "natural", but not as this is meant in linguistics. True enough, we sometimes hear people saying things like: "After two weeks at the Tartu congress, I started to dream in Estonian". This does not mean that the dream language is Estonian; rather, that in a dream some words in any form may be present and that these words are in that natural code. A dream, in itself, has its own idiosyncratic language, and this explains why it is so difficult, afterwards, putting it into words. It is a "multi-code" language, because it can involve all the senses simultaneously. The verbalization of its contents is an intersemiotic translation.

The speed of thought is far higher that the speed of verbalization. Thought is a sort of inner discussion in an inner code understandable only within that framework. Words come into play only when it is necessary to express thoughts outwardly. Vygotsky saw this ability in the infant, who is able to translate outer and inner stimuli into his own inner language and to connect them, to acknowledge (semiotize) them long before learning to actively use the outer language made of words. 
Any attempt to reduce the relations between words to mathematic symbols, any attempt to treat the linguistic code as if it consisted of isomorphic signs, even if we do not take into account all the problems connected to the differences between cultures, is intrinsically ruinous owing to the intrinsically inconsistent nature of the individual-word relationship. Being a product of subjective mental experiences, such relation is also diachronically variable as a function of the progressive enrichment of personal experience.

\section{Text perception}

"The very existence of texts [...] can not only be freely interpreted but also cooperatively generated by the addressee (the 'original' text constituting a flexible type of which many tokens can be legitimately realized) [...]" (Eco 1995: 3). The first act of reading is connected to the perception of the text. Different mental materials, different interpretants, may be linked, in each of us, to a word; consequently, the perception of a word is an interpretive act.

The first stage concerns the interpretive act implied in the very perception of the prototext, i.e. in the first, albeit superficial, reading of the original text. The scanning activity consists in observing parts of a sequence in succession in order to extract meaning, be it a verbal or non-verbal text (Gibson 1983: 250). Even if while reading one seems to get a series of successive optical stimuli, perception actually spans both spatial and temporal order; one can single out not only little fragments, but also complete invariant elements. The initial perception provides an approximate distinction between "same" and "different". Perceived sequences already contain the whole scene: the sequences are converted within the perception of the whole (word, utterance, text; Gibson 1983: 262).

Interpretants, once entered the mind, continue to be modified, producing chain-effects in which they change into signs for further signification processes using as objects other material in - or outside - the mind, and producing new interpretants. Reading, when the text is fertile to the reader, produces long-term reactions.

A translator is reading and, at the same time, has to keep track of all the inner and outer balances the utterance has in connection with the whole text: numerous synthesis and analysis operations are carried out - without the same pressure of the time limitations imposed on 
an interpreter - which force her to focus on the structure as a whole and not only on individual perceptual units (Gibson 1983: 270).

Language has predication capabilities. It has syntagmatic association capabilities, beyond paradigmatic combination capabilities. The endless combinability of words, despite the (supposed) finiteness of each word, greatly increases the predication capabilities and, consequently, the expressive and interpretive potential. Having perceived an object, the observer grasps the affordance of each object, she does not limit herself to the fixed, denotative meaning, she also perceives the connotative, contextual, environmental meaning.

If observer and observed environment are part of one context, it is impossible any kind of objective, detached observation "from without", in the same way as a fixed, cold, unrepeatable reading. According to Heisenberg's indeterminacy principle, absolute and precise measurements are impossible, due to the interference to the measured quantity, which is inevitably introduced by the measuring instrument. In other words, the observer is part of the environment surrounding her as well as the text she is reading, so that each reading, each textual perception is, at the same time, a self-analysis.

\section{Meaning as generalization}

In concept formation, the role played by words is fundamental: first, the infant learns the relation between an object, a situation or a single action and a word. In an experiment, subjects were presented with elements of different shapes, sizes and colors, "experimental blocks", behind which some meaningless strings of characters were traced. The task consisted of establishing conceptual links between shapes, sizes, colors and "new words". Vygotsky concluded that "The formation of the concept is followed by its transfer to other objects: the subject is induced to use the new terms in talking about objects other than the experimental blocks, and to define their meaning in a generalized fashion" (1965: 57)".

Generalization occurs by way of a sort of perception-word-perception-word... chain (i.e. analysis-synthesis-analysis-synthesis...) through which new perceptions induce the formulation of new words to describe them, which induces the systematization of perception so that it will be possible, given a finite number of words, to express infinite perceptions, since two identical perceptions do not exist. Word becomes a means for the formation of concepts (Vygotsky 1965: 59). 
Here's why two readings, even if accomplished in different times by the same person on the same text, are never identical. The meaning of a word is a consequence of the generalization of a concept, of the synthesis of many perceptive experiences: it is an act of thought. Thoughts, words, and meanings are tightly interwoven, and it is probably more interesting to study them as a single system rather than try to isolate components and obstinately demark their limitations (Vygotsky 1965: 120). There cannot be any elaboration of concepts without (at least inner) language and there can be no language without an intense thought activity. But the fruit of such intellectual activity is never fully mature, never truly results as conclusive. Just owing to this back-and-forth play between analysis and synthesis, between perception and generalization - interpretants becoming signs of further Peircean triads -, meaning is an ever-evolving process. The meanings of words are dynamic formations changing with the individual's development and with the various ways in which her thought functions. The relation between thought and word is not a constant but a process, during which changes can be considered "as development in the functional sense" (Vygotsky 1965: 130).

\section{Automatisms}

Ogden and Richards show a more explicitly mental version of Peirce's interpretant that defines the three factors playing a role in any uttering: mental processes, symbol and referent. Between thought and symbol there is a symbolization relation, between thought and object a reference relation, while between symbol and object there is no direct relation, just an implied relationship. The sign-object relation is mediated by the subjective, idiomorphic mind of the person who codes the utterance or decodes it. It is variable, individual, inconstant, indirect.

Reference can be the mnemic effect/s of a stimulus. In this view, reference is a consequence of the adaptation to a psychic context, and "the meaning of $\mathrm{A}$ is that to which the mental process interpreting $\mathrm{A}$ adapts itself. This is the most important sense in which words have meaning". These effects are introspective judgments, i.e. interpretations of a given type, sometimes-nonverbal judgments, "obscure feelings accompanying the reference". Sometimes such feelings are expressed with words, but that is not always the case: sometimes 
words are not appropriate for the reference they must symbolize (Ogden, Richards 1960: 205-206).

While recognizing a sound, or a shape, as such, involves a context consisting of similar, previously experienced sound and visual sensations, recognizing a sign "as a word requires that it form a context with further experiences" other than sounds or graphemes. Without realizing it, one learns to classify the occurrence of a given word as a sign, linked to a reaction similar to those elicited by the associated experiences. Interpretation is unconscious, if no difficulties arise; otherwise, the perceptual automatism can get stuck and conscious interpreting procedures come into play. The fewer difficulties in understanding words, the less consciousness of the processes used in order to do so, and the less preparation to address a marked utterance.

Once a sound is mentally identified as a word, its importance as a sound is not placed in the background. Some phonic (tone, volume, speed, timbre, intonation, musicality) and graphic features (typeface/ handwriting, spacing, dimension, layout, graphics) become part of the message content and, as much as two encounters with the same word can prove to be different, they must share that common character necessary to identify them as occurrences of the same word. Only thanks to this shared part the two words have a similar psychic context, and hence can be perceived in a similar way. Such psychic contextualization occurs, particularly in the first, simpler stages, in an unconscious way. Difficulty in understanding generates the reemergence of non-conscious levels (Ogden, Richards 1960: 211), and focusing onto such usually automatic mechanisms, which distracts from the interpretation of the message at a pragmatic, functional, outer level.

\section{Metaphor and free associations}

Language learning is not a simple matter of acquiring synonyms or alternative expressions, but to learn the nuances of many senses and particular connotations created by the context. Such endless activity of identification of affinities and differences continually refines abstraction capabilities, teaches to use metaphors, "the primitive symbolization of abstraction". Metaphor is the application of a single verbal expression to a group of objects that are different but share something. The use of metaphor helps the identification of a similar relation in 
another group. Metaphor is a signification relation that appropriates the context of another relation.

The abstraction capability necessary to get to the metaphor is just the same as that necessary to put an adjective near a noun, or to use prepositions or verbs. And the metaphorical aspects of a great part of language show that, the higher the level of education of an individual, the more words acquire a context through other words. The down side of such sophisticated acquisition of meanings lies in the fact that meanings, built on such abstract references, are bound to muddle our minds more often.

Unlike numbers, words express the attitude of the speaker toward objects. "A word is nothing but a metaphor for an object or, in some cases, for another word" (Rabassa 1989: 1). An implicit comparison implies a peculiar way of expressing the indicated object, not a "neutral" expression of it.

Rabassa recalls a passage from the Gulliver's Travels in which, at Lagado Academy, the problem of the margin of misunderstanding is resolved in a very original, if not very practical, way: everyone carries every object he wants to "talk" about and, instead of talking, shows the object. While in our reality the two triangles sign-interpretantobject of interlingual translation face one another, with the translator in an uncomfortable position between the two signs, in the case of Lagado's academics, the interpretive triangle formed by object, interpretant, sign in the prototext would share one vertex with the relative interpretive triangle of the metatext: the object vertex. Borges, in order to stress the inadequacy of words, proposed one of his translators not to translate what he said, but what he meant to say. Since a writer does nothing but choose the metaphor that best becomes the sense of what he wants to express (Rabassa 1989), and since, evidently, metaphors are all but scientifically formed, the translator must abductively reconstruct the process that induced the author to use given metaphors and then she has to understand the author's presumed communication intention: a psychological task.

\section{Reading as translation}

While reading, one doesn't store the words read in her mind as happens with data entered by keyboard or scanner into a computer. After reading, there is no photographic or auditory recording of the text read. 
There is a set of impressions. A few words or sentences are remembered precisely, while all the remaining text is translated into mental language. The first act in translating the translator must carry out is intersemiotic, not interlingual. The words are transformed into mental material. Far from being an objective reaction to the graphic sign, a standard biochemical reaction equal for all the readers dealing with the perception of any given word, the interpretant is a subjective psychic sign, produced by the whole experience accomplished by the individual with words, objects, concepts or feelings linked, by any means, to the word in question. An interpretant is subjective because the experience each of us has is subjective.

Experiments were carried out on readers in order to explain how syntactic and semantic ambiguities may be solved during the act of reading. Some of the examples on which the experiments were carried out are based on the completion of incomplete utterances.

1) Henry forgot Lila...

a) $\quad . .$. at her office. (direct object interpretation);

b) ... was almost always right. (sentence complement interpretation). (Trueswell 2000: 327)

When faced with ambiguities like the one in the first utterance, experiments indicate that readers tend to resolve ambiguities. In the quoted example most readers opted for the (a) interpretation. A theory of sentence processing has been created that emphasizes the integrative nature of interpretation: ambiguities are resolved, having considered a wide range of sources of information, based on restraints that prevent different interpretations.

As much as a polysemic word has meanings that are dominant when compared to others - i.e. meanings that are considered more probable a priori out of context - ambiguous words can have a priori dominant and/or subordinate syntactic structures. Experiments show that the fact that a structure is or is not dominant changes from one instance to another, from one word to another. And probably it varies from one culture to another too, even within the same natural code, and from one speaker to another (Trueswell 2000: 331-332).

Two kinds of restraints - how frequent the experience with a syntactic structure has been and the presence of the semantic and cotextual information - do not occur in sequence, but simultaneously, in a reciprocal interaction. This was controlled based on the presupposition that, when one of the limiting factors contradicts with the other, the time required to resolve the ambiguity increases. In order to 
know the odds that a given syntactic pattern or a given semantic value will be used within a given speaker's community, textual corpora were used containing millions and millions of 'real' utterances. When readers come across the clue that lets them think of a very probable structure that, however, develops in an unexpected way, they take much more time in the process of resolving the ambiguity.

\section{Writing as a translation process}

Researchers dealing with text generation agree on the fact that it is a translation process - within the wider interlingual translation process - and to describe it spontaneously use the word "translate" and its derivatives: "Text or discourse production basically consists in determining, organizing and translating content [...], the translation of a conceptual structure (message) into its corresponding linguistic form" (Zock 1997: 317). The human mind processes language by taking it apart - unconsciously: it's all too fast for a conscious control to be active - into "translation units", conceptual chunks that may correspond to nominal groups, propositions, but never single words (Zock 1997: 318). Word-for-word elaboration can block sentence formulation: not knowing from start what persons are the subjects/ objects of the action it is often impossible to go on formulating the sentence.

The length of the chunks used by the single individual as a processing unit depends, on the complexity of the concepts and on the technical competence. An interlingual translator is no exception to this rule: the more expert, the greater the text chunks. Mental chunks are translated into words, each of which has syntagmatic and paradigmatic properties. The cognitive process on which verbalization is based tends to be repeated as it is, resulting in verbal habits (Zock 1997: 323). A first lexical draft of the mental content to be expressed is sometimes realized in this way, looking for approximate matching between previous writing experiences and what needs to be expressed. This pattern matching produces a first approximate draft, comparable to what Freud calls "primary process" referring to dream lexicalization. Such first stage implies, especially in the more expert and skilled writers, a second stage of reviewing and adjusting ("secondary process") (Freud 1900: 525). Due to limitations in short-term memory, sentences are built gradually, interpolating execution and planning 
stages. While one part of the speech act is actualized, the next one is planned. There are many affinities between language and perception: they are both compositional devices, both must satisfy good-form and completeness (Gestalt) conditions (Zock 1997: 328).

If the text-generation process is considered in terms of intersemiotic translation from the mental into the verbal, and if applying words to mental content generates content, then the translation process is complex, bi-directional, and manifold. If the selection of given words alters the content of the message to be expressed, such selection has an impact both on the structuring of that message and on all revisions before the final draft.

There is no describable correspondence between words and the mental subjective meaning aura: choosing a word (or combination) alters not only the way in which content is expressed, but the speech act's content as well. Such a view supports the Russian Formalists' point about indivisibility of form and content. This is also because verbal language proceeds along a paradigmatic-syntagmatic line, while thought is more similar to a hypertext.

Speaking of metatext drafting in terms of translation from the mental into the verbal, I give an approximate, general idea. Going into details one realizes that, actually, there is a series of micro-translations that, like shuttles, move in the two ways from verbal to mental and vice versa. After the first approximate translation of mental material into lexicon, the semantic fields of the selected words, together with their syntactical combinability, the connotative meanings of these words for the writing person, the cognitive experiences connected to the use of such words by the subject determine an informational feedback (from verbal into mental) that influences the selection of other words and the completion and/or modification of syntactical structures (from mental into verbal).

Both the stage in which the text of a translation is drafted, and the stage in which the metatext is revised, add up to a continuous work of micro-translation from the mental into verbal and vice versa that ends only with actualization.

\section{Interminable/terminable (text) analysis}

A sign, or representamen, is something which stands to somebody for something in some respect or capacity. It addresses somebody, that is, creates in the mind of that person an equivalent sign, or perhaps a more developed 
sign. That sign which it creates I call the interpretant of the first sign. The sign stands for something, its object. It stands for that object, not in all respects, but in reference to a sort of idea, which I have sometimes called the ground of the representation. (Peirce 1931-1966, 2: 228)

One object, depending on the ground on which the consideration lies, has different interpretants. Eco focuses on getting to a wider context in which it is possible to explain why two speakers usually can understand each other, at least partially, while their communicative capacity is based on subjective instances. "[...] A ground is an idea in the sense in which an idea is caught during the communicative intercourse between two interpreters" (Eco 1995: 183). Although the interpretant is subjective, there exists a pragmatic use of words that, taking into account the actual communicative relation between two persons, relies on that part of the interpretants that can be presumably shared. The meaning of a sign is null in itself, it only becomes something in the relation with the pragmatics of communication, it becomes something only in translation. Meaning " $[. .$.$] is, in its primary acception, the translation of a sign into$ another system of signs" (Peirce 1931-1966, 4: 127). "[...] the meaning of a sign is the sign it has to be translated into" (Peirce 1931-1966, 4: 127). The sign-interpretant-object triad thus does not contemplate the notion of "meaning" until the semiotic process is not actualized. The meaning of a word is representable as a network of features regarding that term (Eco 1995: 187). Following Peirce, unlimited semiosis is apparently a strict consequence of the semiotic theory, but it eventually takes on the form, in some of its representations, the anguished aspect of the interminability not only of the analysis of meanings, but also of the search for understanding, like in this passage:

The object of representation can be nothing but a representation of which the first representation is the interpretant. But an endless series of representations, each representing the one behind it, may be conceived to have an absolute object as its limit. The meaning of a representation can be nothing but a representation. In fact, it is nothing but the representation itself conceived as stripped of irrelevant clothing. But this clothing never can be completely stripped off; it is only changed for something more diaphanous. So there is an infinite regression here. Finally, the interpretant is nothing but another representation to which the torch of truth is handled along; and as representation, it has its interpretant again. Lo, another infinite series. (Peirce 1931-1966, 1: 339)

In Eco's opinion essentially the interpretant produced by an object has a double nature. On one hand there is the affect that constitutes the link between an object and a sign. Interpretations, within affective interpretants, have consequences within the framework of representations, 
without altering anyone's behavior. The "energetic interpretant" is, on the other hand, the one producing a change of habit (Eco 1995: 194). When this apparently endless series of representations of representations leaves the mental context to enter the practical sphere, causing a different behavior, "our way of acting within the world is either transitorily or permanently changed" (Eco 1995: 194).

The semiotic process ends when the translator chooses a concrete translatant, but it would be an illusion to pretend that this is the end: "[...] the repeated action responding to a given sign becomes in its turn a new sign, the representamen of a law interpreting the former sign and giving rise to new processes of interpretation" (Eco 1995: 195). The translating text sets an end to the otherwise unlimited semiosis of the prototext, but sets in motion a new chain of unlimited semiosis based on new signs, new texts, new interpretations.

As in psychoanalysis, where the question posed is "terminable or interminable analysis?", in translation we also face a supposedly endless series of interpretations. And the more fertile a text is, the easier to ascertain such interminability. "Explorations of semantic structure very soon raise the problem of infinite series. Wittgenstein asked where, when, and by what rationally established criterion the process of free yet potentially linked and significant association in psychoanalysis could be said to have a stop. An exercise in 'total reading' is also potentially unending" (Steiner 1992: 8). Language evolves with historical, but also subjective, time. Moreover, the metalinguistic assertions about language are destined to modify the very language one is talking about; our subject is therefore very plastic and difficult to catch in a moment of stasis. "When we think about language, the object of our reflection alters in the process" (Steiner 1992: 18). Each word or locution carries also with it its history, so that a full reading (Steiner 1992: 24) evokes not only immediately accessible meanings, but also other vague allusions.

But, Steiner argues on Wittgenstein's footprints, the moment in which the analyst - for any reason - interrupts the patient is arbitrarily chosen. In much the same way, the moment in which the translator actualizes the prototext in the metatext is arbitrarily chosen. 


\section{Translation and Freudian psychoanalysis}

The dream theory has a strong potential as a contribution to understanding the mechanisms of translation, of reading in particular.

"It is impossible as a rule to translate a dream into a foreign language and this is equally true, I fancy, of a book such as the present one" (Freud 1900: 104). Freud himself is the first to lay the basis for the total translation view with this extended metaphor of a dream as a text. The dream is one of many types of text, its interpretation is one of many kinds of translation and, to be precise, it is a multiple translation.

First the dreamer - dealing with often fragmentary memories of images, sounds, sometimes conversations in many languages sometimes invented, scenes occurring without any evident logic, smells, tactile sensations - verbalizes this material in order to be able to report it. Secondly, the therapist translates the dreamer's report and abductively reconstructs the dream thoughts. The dream thoughts and the dream's content present themselves as two versions of the same subject in two different languages. The content (patient's telling) is a sort of transcription (Übertragung) of the dream thoughts in another expressive mode. Comparing prototext and metatext, the translator (psychoanalyst) must understand characters and syntactic laws of the dream, with an abductive process. What in textology is considered the author's strategy, that the translator-critic tries to unveil starting from the text (result), here is the strategy of the manipulation of unconscious thoughts (latent content), that the psychoanalyst tries to unveil starting from the manifest content of the dream (result).

The unconscious uses a sort of 'incomprehensible translation' to express repressed mental material — as it is inconvenient for Ego functioning - in the shape of symptomatic acts, dreams, inexplicable behaviors. The metatext of such incomprehensible translation is called "manifest content" and the psychoanalyst's aim is to back-translate it into "latent content". Anyone attempting to understand one's own dream using an interpretive key founded on the existence of the unconscious and of its dream expression finds herself in the same position as the critic-reader of a translation trying to understand, from the result (metatext), what translation strategy was adopted, without the possibility - granted to the critic of the verbal translation - to compare the metatext to the prototext: a real abductive process.

Persons desiring to learn to interpret dreams are polyglot translators facing a text aware of their ignorance of the code both in lexical 
and in syntactical terms. It is maybe comparable to someone wanting to listen to the dialogue of two unknown persons randomly encountered whose code must be abduced in order to make sense of their dialogue's content.

In dream theory, the primary process is the translation of the prototext into words, while the secondary process transforms the words - metatext of the previous operation - into a new prototext, and its aim is to produce a second metatext that, more than being made of words, has a textual coherence and cohesion. The secondary process intervenes to fill gaps in the syntax in the primary text's understandability. The former element has the goal of changing the message code, the latter to make it usable. The risk is that readability corrupts the prototext's (dream's) meaning. Textual cohesion that in the metatext derives from secondary processing is not always matched by textual cohesion in the prototext. Sometimes such cohesion is produced by the translator's (or dreamer's) over-mediation.

The extension of total translation to the mind/verbal expression, dream/interpretation dialectics is both coherent with the spirit of such theory and productive on the plane of reciprocal enrichment of psychological theory and translation studies, in particular, the theory of reading.

\section{Defenses}

The translator of the official English version of Freud's works, James Strachey, seems to have overlapped to Freudian view and its expression an ideology more typical of the British psychoanalysis of Jones, tending to 'science-ize' the metaphorical and evocative form of Freudian concepts. The translator runs the constant risk of working like Strachey did, manipulating the text according to her views, when different from the author's. "If ... the translator is not fully aware of the important yet sometimes subtle differences - professional, political, and social between his views and those of the person translated, various ideological distortions are bound to creep into the secondary text. The more complex the source text is, the more the translator should be self-aware of his own different positions and their contaminatory potential" (Mahony 1994: 321-322).

Psychology can make an essential contribution to translation science also in the last stages of the translation process: the metatext's 
revision by the translator and, when applicable, by the editor or a critic, in the latter case meaning a review.

In the light of the passage of the text through a stage of psychic material, the difficulty of self-correction, of maintaining a self-critical attitude toward the previous draft is understandable. The equilibrium of the ego is safeguarded by defenses censoring certain aspects of reality to the advantage of the stability and functioning of the individual. Since it can be very distressing for a translator to realize that a former product of his efforts - as it may well sometimes happen - is awkward, clumsy, not fully coherent, i.e. not completely a text in the etymological sense, mechanisms may kick in that alter the perception of such a text causing the translator to see it as better than it really is, to the detriment of self-criticism abilities. Since interpretants are continually evolving, allowing some time to lapse between the first draft and revision helps increase self-critical ability, detachment: a text that some time ago was perceived as one's own, is now perceived (mostly) as other's, and therefore it is more easily criticized.

As to revisions of translations by editors, the problems are multiplied owing to the subjective perception of language. Idiosyncrasies and personal preferences for given expression modes, different textual experiences, sometimes even different communicative purposes can determine irreconcilable differences between translator and editor, resulting in compromises in which the mediation possibilities are a direct function of power relationships existing between translator and editor (or publisher represented by the editor).

In the field of translation reviews, the fact that a text is translated from another language is often completely neglected, as is implied in the translation approach dubbed "acceptable" by Toury. Such a translation therefore emerges as a fiction within fiction. But also for translations whose identity as metatexts is self-evident, the review often neglects to mention all the aspects concerning the translation, limiting itself to a review of the original. This line of thinking neglects not only the way the translation mediates between transmitting culture and receiving culture, but also represses the question of the receptivity of a culture to given alien texts, taking for granted that the acceptance of the metatext in the receiving culture is the same as in the culture that produced the prototext. In this field, psychology is, therefore, helpful for understanding the reasons why any given culture tends to confine the existence of the "system of translated literature within the literary polysystem" (Toury) to a wholly or partially unconscious 
existence, and to understand the possible interaction between the translator's hermeneutics and the critic's.

\section{Didactic spin-off}

Since such contributions of psychology to translation radically modify the view of translation activity, it is important to acknowledge them right from the first stages of the translator's education. For this reason, in the courses of translation propaedeutic (and in the book I have published under the same title) — for the first year of university translation courses - I devote an important part to these problems.

\section{References}

Bell, Roger T. 1998. Psycholinguistic/cognitive approaches. In: Baker, Mona (ed.), The Routledge Encyclopedia of Translation Studies. London: Routledge, 186-190.

Calvino, Italo 1998. If on a Winter's Night a Traveller. Translated by William Weaver. London: Vintage.

Crowder, Robert G.; Wagner, Richard K. 1992. The Psychology of Reading: An Introduction. New York: Oxford University Press.

Eco, Umberto 1995. The Role of the Reader. Explorations in the Semiotics of Texts. Bloomington: Indiana University Press.

- 1981 [1979]. Lector in fibula: La cooperazione interpretativa nei testi narrativi. Milano: Bompiani.

Freud, Sigmund 1900. Die Traumdeutung. Leipzig, Deuticke.

Gibson, J. J. 1983 [1966]. The Senses Considered as Perceptual Systems. Westport: Greenwood Press.

Gorlée, Dinda L. 1994. Semiotics and the Problem of Translation with Special Reference to the Semiotics of C. S. Peirce. Amsterdam: Rodopi.

Levelt, Willem J. M. 1989. Speaking: From Intention to Articulation. Cambridge: MIT Press.

Mahony, P. 1994. Hermeneutics and ideology: on translating Freud. Meta. Journal des traductuers. Translators's Journal 39(2): 316-324.

Ogden, C. K.; Richards, I. A. 1960 [1923]. The Meaning of Meaning: A Study of the Influence of Language upon Thought and of the Science of Symbolism. London: Routledge \& Kegan Paul.

Osimo, Bruno 2001. Propedeutica della traduzione. Milano: Hoepli.

Peirce, Charles Sanders 1931-1966. Collected Papers of Charles Sanders Peirce. 8 vols. Hartshorne, Charles; Weiss, Paul; Burks, Arthur W. (eds.). Cambridge: Belknap. 
- 1982. Writings of Charles S. Peirce: A Chronological Edition. Fisch, Max; Moore, Edward C.; Kloesel, Christian J. W.; et al. (eds.). Bloomington: Indiana University Press.

Rabassa, Gregory 1989. No two snowflakes are alike: translation as metaphor. In: Biguenet, John; Schulte, Rainer (eds), The Craft of Translation. Chicago: University of Chicago Press, 1-12.

Rupprecht, Carol Schreier 1999. Dreaming and the impossible art of translation. Dreaming. Journal of the Association for Study of Dreams 9(1): 71-100.

Steiner, George 1992. After Babel: Aspects of Language and Translation. 2nd ed. Oxford: Oxford University Press.

Torop, P. 1995. Total'nyj perevod. Tartu: Tartu University Press.

Trueswell, John C. 2000. The organization and use of the lexicon for language comprehension. In: Landau, Barbara; Sabini, John; Jonides, John; Newport, Elissa (eds.), Perception, Cognition, and Language. Essays in Honor of Henry and Lila Gleitman. Cambridge: The MIT Press, 327-345.

Vygotsky, L. S. 1965 [1934]. Thought and Language. Hanfmann, Eugenia; Vakar, Gertrude (eds.). Cambridge: MIT Press.

Zock M. 1997 Sentence generation by pattern matching: the problem of syntactic choice. In: Mitkov, R.; Nicolov, N. (eds), Recent Advances in Natural Language Processing. (Series: Current Issues in Linguistic Theory.). Amsterdam: Benjamins, 317-352.

\section{О психологических аспектах перевода}

Переводоведение переживает этап самоопределения. Статья Якобсона “О лингвистических аспектах перевода"(повлиявшая и на заглавие данной статьи), несмотря на ориентированность на лингвистику, открывает в 1959 г. дорогу для изучения перевода другими дисциплинами, включая семиотику. Многие направления в семиотике перевода, особенно теория тотального перевода Торопа, исходят из примененного в той же статье 1959 г. понятия “интерсемиотического перевода или трансмутации”. Я хотел бы отметить возможное влияние на переводоведение - в духе семиотической перспективы, открытой Пирсом и продолжаемой Торопом, - другой дисциплины, психологии. “Тотальный” подход к переводу, предложенный Торопом, может быть дополнен применением психологического подхода в рассмотрении понятия "интерпретанта" в качестве ментального знака; в перцептивной интерпретации прототекста; в рассмотрении чтения и писания как интерсемиотического процесса перевода, а безграничного семиозиса - как бесконечного анализа; в наблюдении первичных и вторичных процессов в сновидениях и в других видах перевода; в рассмотрении метафоры и конкретизации как ментальных процессов; в описании защитного механизма, активизируемого в ходе критики перевода (обзор) и самокритики (ревизия). 


\section{Tõlkimise psühholoogilised aspektid}

Tõlketeadus on läbimas oma enesemääratlemise etappi. Jakobsoni artikkel "Tõlkimise lingvistilised aspektid", mille pealkiri kajastub antud artikli pealkirjas, avab 1959. aastal, vaatamata viitamisele lingvistikale, tee tõlkimise uurimisele teiste distsipliinide poolt, semiootika kaasa arvatud. Mitmed arengusuunad tõlkesemiootikas, eriti Toropi totaaltõlke teooria, lähtuvad samast 1959. a. artiklist pärinevast kuulsast "intersemiootilise tõlke ehk transmutatsiooni" mõistest. Ma tahaksin siin osutada mõjutusele, mis võiks tõlketeadusesse - järgides semiootilist perspektiivi, mille avas Peirce ja mida on jätkanud Torop — tulla teiselt distsipliinilt, psühholoogialt. "Totalistlikku" lähenemist tõlkimisele, mida Torop esindab, võiks täiendada psühholoogilise lähenemise rakendamine seoses mõiste "interpretant" käsitlemisega mentaalse märgina; prototeksti pertseptiivse interpreteerimisega; lugemise ja kirjutamise vaatlemisega intersemiootilise tõlkeprotsessina; piiritu semioosi käsitlemisega lõputu analüüsina; primaarse ja sekundaarse protsessiga unenägudes ja muudes tõlkeliikides; metafoori ja konkretiseerimise käsitlemisega mentaalse protsessina; kaitsemehhanismiga, mis aktiviseerub tõlkekriitika (ülevaade) ja enesekriitika (revisjon) käigus. 